\title{
A report of a child with a deletion (9)(q34.3): a recognisable phenotype?
}

\author{
H Ayyash, R Mueller, E Maltby, P Horsfield, N Telford, R Tyler
}

\begin{abstract}
We report a case of a male infant who presented with congenital anomalies and was found to have a de novo deletion in the terminal region of the long arm of chromosome 9. He died at the age of 17 weeks of cardiorespiratory failure owing to RSV positive bronchiolitis. A review of previously published reports documented one previous report of a patient with a deletion of (9)(q34.3) and multiple congenital anomalies. Comparison with the previously reported case suggests that the phenotype observed constitutes a clinically recognisable pattern of malformations.

$(\mathfrak{F}$ Med Genet 1997;34:610-612)
\end{abstract}

Keywords: chromosome deletion (9)(q34.3); partial monosomy 9q; congenital heart disease; multiple congenital malformation

We describe the phenotype of an infant with multiple congenital anomalies who had a de novo deletion in the terminal band of the long arm of chromosome 9: 46,XY,del(9)(q34.3). There is one previous case report of an infant with deletion (9)(q34.3). ${ }^{1}$ The previously described infant and our patient share the common manifestations of developmental delay, growth failure, hypotonia, microcephaly, epicanthic folds, downward slanting palpebral fissures, hypoplastic midface, flat nasal bridge with a small nose, single umbilical artery, natal teeth, low set ears, gastro-oesophageal reflux, and heart defect. The deletion was not detected on initial routine chromosome analysis, but was only noted at higher resolution chromosome banding, illustrating the need for repeat karyotyping with improved resolution when there is strong clinical suspicion of this chromosome abnormality.

\section{Case report}

The proband was the male child of nonconsanguineous white parents, born at 38 weeks' gestation by spontaneous vaginal delivery to a 25 year old, gravida 4 , para 4 mother. His sibs were entirely normal and both parents were healthy with no family history of miscarriages, stillbirths, congenital abnormalities, or learning difficulties. The pregnancy was normal with no known exposure to viral infection or medications. A single umbilical artery was noted on routine antenatal scan and after birth. The birth weight was $3010 \mathrm{~g}$ (10th centile), length $49 \mathrm{~cm}$ (>10th centile), and head circumference was 30.3 ( $<3$ rd centile). Apgar scores were 7 and 9 at one and five minutes respectively. $\mathrm{He}$ was noted to have unusual facial features in the neonatal period, which included microcephaly with receding forehead, hypertelorism, flat nasal bridge, flat occiput, large posterior fontanelle with separated sutures, epicanthic folds, downward slanting palpebral fissures, low hair line, and a large, protruding tongue. A natal tooth was present on the anterior lower alveolar ridge. The palate was intact. He had low set ears, flat hand and foot pads, a sacral dimple, a single transverse palmar crease on the right hand, and large toes with overlapping of the fourth and fifth toes on both feet. He was hypotonic. The external genitalia were those of a normal male. Because of these dysmorphic features a peripheral blood sample was sent for chromosome analysis which was reported as normal, $46, \mathrm{XY}$.

He required tube feeding during the first two days owing to poor feeding. He was discharged home on day 3 feeding satisfactorily. At the age of 19 days he was admitted again because of lethargy, poor feeding, and vomiting, and was found to be in heart failure. He had a holosystolic heart murmur grade $3 / 6$. The following investigations were normal: a septic screen including lumbar puncture, routine serum biochemistry, haematological indices, plasma and urinary amino and organic acid screens, thyroid function tests, brain and renal ultrasound, and skeletal survey. An ECG showed right ventricular hypertrophy. Echocardiography showed a large ventricular septal defect, left to right shunt, right ventricular hypertrophy, and dilatation of the main pulmonary artery consistent with pulmonary hypertension.

At the age of $31 / 2$ weeks an extraction of the natal teeth was performed. At 7 weeks of age, because of a continuing need for tube feeding and vomiting, a barium swallow was performed which showed gastro-oesophageal reflux. He was noticed to have seborrhoeic dermatitis on the scalp, eczematous lesions on the face, and a small umbilical hernia. At the age of 16 weeks he remained hypotonic and his weight, length, and OFC were all below and parallel to the third centile. He was noted to have developmental delay. $\mathrm{He}$ was unable to raise his head and had no social smile. Ophthalmological examination showed him to have horizontal nystagmus; he was able to fix and follow light or large targets only momentarily. Brain stem threshold testing performed on several occasions showed that he had profound hearing loss. 
He became gradually more tachypnoeic with recession and crepitations despite being on regular diuretics and captopril. He twice had

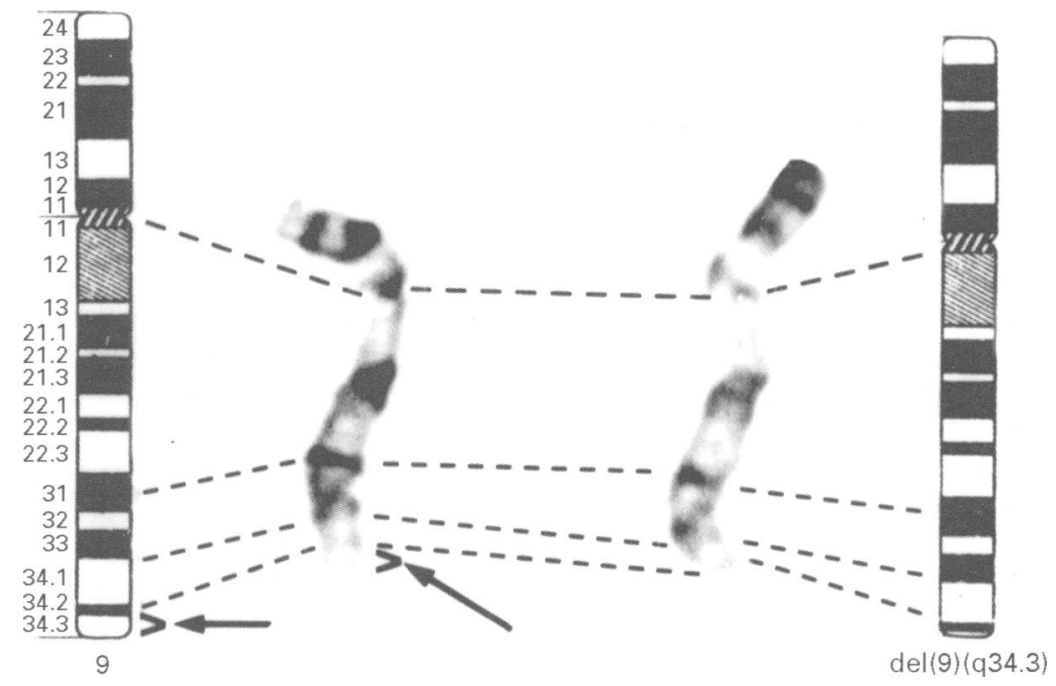

Figure 1 Ideogram and partial deletion of proband's chromosome 9 from peripheral blood sample.

Table 1 Clinical features of cases with deletions $9 q$

\begin{tabular}{|c|c|c|c|c|}
\hline & \multicolumn{4}{|l|}{ Cases } \\
\hline & $1^{2}$ & $2^{3}$ & $3^{\prime}$ & Present case \\
\hline Cytogenetics & $\operatorname{del}(9)(\mathrm{q} 32 \mathrm{q} 34)$ & $\begin{array}{c}\operatorname{del}(9)(\mathrm{q} 22 \mathrm{q} 32) \\
\text { or } \\
\operatorname{del}(9)(\mathrm{q} 32 \mathrm{q} 34)\end{array}$ & $\operatorname{del}(9)(\mathrm{q} 34.3)$ & $\operatorname{del}(9)(\mathrm{q} 34.3)$ \\
\hline Sex & $\mathbf{M}$ & $\mathrm{F}$ & $\mathbf{M}$ & $\mathrm{M}$ \\
\hline Weight (centile) & 3 rd & 25th (28 mth) & $<5$ th $(5 \mathrm{mth})$ & 10 th \\
\hline Height (centile) & 3 rd & 25 th & $<5$ th & $>10$ th \\
\hline $\begin{array}{l}\text { Head circumference (centile) } \\
\text { Development }\end{array}$ & & 2nd & $<5$ th & $<3$ rd \\
\hline Mental delay & + & + & + & + \\
\hline Hypotonia & + & + & + & + \\
\hline Cranium & & & & \\
\hline Microcephaly & & + & + & + \\
\hline Dolichocephaly & - & - & + & - \\
\hline Trigonocephaly & - & + & - & - \\
\hline Brachycephaly & + & - & - & - \\
\hline $\begin{array}{l}\text { Frontal bossing/prominent } \\
\text { forehead }\end{array}$ & + & - & + & + \\
\hline Midface hypoplasia & + & & + & + \\
\hline $\begin{array}{l}\text { Flat supraoorbital ridges } \\
\text { Eyes }\end{array}$ & + & & + & + \\
\hline $\begin{array}{l}\text { Downward slanting palpebral } \\
\text { fissures }\end{array}$ & + & + & + & + \\
\hline Epicanthus & & + & + & + \\
\hline Hypertelorism & + & + & + & + \\
\hline $\begin{array}{l}\text { Nystagmus } \\
\text { Nose }\end{array}$ & - & - & - & + \\
\hline Short nose & + & - & + & + \\
\hline $\begin{array}{l}\text { Deep nasal bridge } \\
\text { Mouth }\end{array}$ & + & - & + & + \\
\hline Natal teeth & - & - & + & + \\
\hline Large, protruding tongue & - & - & - & + \\
\hline $\begin{array}{l}\text { Intact, high arched palate } \\
\text { Ears }\end{array}$ & & + & + & + \\
\hline $\begin{array}{l}\text { Low set } \\
\text { Trunk }\end{array}$ & + & + & + & + \\
\hline Pectus excavatum & - & - & + & - \\
\hline Heart defect & $?$ & - & + & + \\
\hline VSD & - & - & - & + \\
\hline Coarctation & $?$ & - & - & - \\
\hline $\begin{array}{l}\text { Concealed accessory } \\
\text { connection }\end{array}$ & - & - & + & - \\
\hline Tracheomalacia & & & + & + \\
\hline Gut malrotation & & & + & - \\
\hline $\begin{array}{l}\text { Abnormal genitalia } \\
\text { Umbilicus }\end{array}$ & + & - & + & - \\
\hline Single umbilical artery & & & + & + \\
\hline $\begin{array}{l}\text { Hernia } \\
\text { Hands/feet }\end{array}$ & + & + & - & + \\
\hline Single palmar crease & + & + & + & + \\
\hline Abnormal toes & + & + & + & + \\
\hline Talipes equinovarus & - & - & + & - \\
\hline
\end{tabular}

+=present, -=absent, blank=not mentioned. lingular consolidation. He continued to require nasogastric tube feeding and needed $35 \%$ oxygen to maintain his oxygen saturation above $90 \%$. At 5 months of age he developed an increasing cough and wheeze. Respiratory syncytial virus was identified in nasopharyngeal aspirate. He deteriorated over the following days despite the administration of bronchodilators and Ribavirin. He died of cardiorespiratory failure from bronchiolitis at the age of 17 weeks. Consent for necropsy was not given.

\section{CYTOGENETICS}

Because of the likelihood of a chromosomal abnormality, a skin biopsy was taken which showed a microdeletion in the terminal band of the long arm of chromosome 9. Fluorescent in situ hypridisation with a gene probe for the C abl locus which maps to band 9q34.1 was normal, suggesting that the deletion was more distal in the region $\mathrm{q} 34.2-\mathrm{q} 34.3$. G banding analysis which was performed on a second peripheral blood sample, at the age of 3 weeks, showed all cells to contain a subtle deletion of the terminal portion of chromosome 9 involving subband 9q34.3 (fig 1). Unfortunately, there was insufficient material from the case to allow investigation by a chromosome 9 telomere probe and we were unable to confirm deletion of the telomere. No cell line is available from the patient. Parental chromosomes were normal.

\section{Discussion}

A limited number of cases of distal interstitial deletion or terminal deletion of the long arm of chromosome 9 have been reported (table 1). ${ }^{1-3}$ Turleau et al described an infant with multiple congenital anomalies in whom a de novo deletion of (9) (q32q34) was found. Farrell et al described three cases and reviewed another seven previously published cases with interstitial deletions spanning from $9 \mathrm{q} 11$ to $9 \mathrm{q} 34$. A definite syndrome was not identified among the patients and no distinct pattern of clinical features emerged. The probable explanations for the diversity of features are likely to result from different breakpoints of the deletions and, as described by Schinzel, ${ }^{4}$ the incidence and severity of major malformations correlates with the size of the deleted segment, but the pattern of dysmorphic features shows little correlation with the size of the unbalanced segment. Except for one case reported by Schimmenti et $a l,{ }^{1}$ there have been no previous reports, to our knowledge, limited to a deletion (9)(q34.3). The findings in our patient are similar to those described previously by Schimmenti et al. ${ }^{1}$ Their case fed poorly and underwent a Nissen fundoplication and placement of gastrostomy tube, ours gained weight with thickened nasogastric feeds. Both cases had chronic dyspnoea with hypoxia in air along with varying lobar consolidation. The case of Schimmenti et $a l^{1}$ was diagnosed as having tracheomalacia, and our case history is consistent with that, and both died at the age of $4 / 5$ months (personal communication) of acute on chronic respiratory failure. 
We think that our patient with a deletion of (9)(q34.3) represents a recognisable pattern of malformation. This deletion is associated with severe developmental delay and severe respiratory difficulty leading to premature death. Chromosomal deletion of this region may occur more frequently than has been previously recognised and as a consequence high resolution chromosome analysis should be considered in patients with these clinical features.

We are grateful to Professor Lisa Schimmenti, MD, University of California, Los Angeles, USA, for her encouragement and support during the preparation of this manuscript and to our senior paediatric secretary, Mrs Margaret White, for her assistance.

1 Schimmenti LA, Berry SA, Tuchman M, Hirsch B. Infant with multiple congenital anomalies and deletion (9)(q34.3). Am f Med Genet 1994;51:140-2.

2 Turleau C, De Grouchy J, Chabrolle JP. Deletions intercalaires de 9q. Ann Genet (Paris) 1978;21:234-6.

3 Farrell SA, Siegel-Bartelt J, Teshima I. Patients with deletions of $9 q 22 q 34$ do not define a syndrome: three case reports and literature review. Clin Genet 1991;40:207-14.

4 Schinzel A. Phenotype in autosomal chromosome aberrations: distinctiveness, variability, and karyotype correlations. In: Daniel A, ed. The cytogenetics of mammalian autosomal rearrangements. New York, Alan R Liss, 1988.

\section{$\frac{c}{3}$

